\title{
Numerical Study of the Water Flow Effect on the Water Level in the Don Mouth
}

\author{
A. L. Chikin ${ }^{1 *}$, A. V. Kleshchenkov ${ }^{1}$, L. G. Chikina ${ }^{2}$ \\ ${ }^{1}$ Federal Research Centre the Southern Scientific Centre of Russian Academy of Sciences, \\ Rostov-on-Don, Russian Federation \\ ${ }^{2}$ Southern Federal University, Rostov-on-Don, Russian Federation \\ *chikin1956@gmail.com
}

\begin{abstract}
Purpose. The purpose of the paper is to determine the patterns of the level regime formation in the Don riverbed and the delta area of its valley at different volumes of the river flow discharge and water levels in the Taganrog Bay.

Methods and Results. The mathematical model of the river Don flow in its delta area is described. The mainstream consisting of several reaches is considered at its running into the receiving reservoir - the Taganrog Bay. The model is described by the Saint-Venant system of equations, which is solved by the finite-difference methods. The equations are approximated at the four-point template that leads to the system of linear equations with a five-diagonal matrix. Roughness coefficients were selected for different water flow discharges. The simulated values of the water flow discharge and the flow velocity are compared with the values observed at different water levels in the Taganrog Bay. The results of the numerical study of the water flow effect at the estuary top upon the water surface level in the riverbed were obtained at different water levels in the receiving reservoir. It is numerically defined that the flow discharge value exerts a significant effect on the surface level of the Don mainstream. However, the flow almost does not influence the water level in the river delta area. At the same time, the water level in the Taganrog Bay significantly affects the surface level in the delta reaches; and no its influence is observed in the top part of the riverbed.

Conclusions. The computational experiments involving the mathematical model showed that in the mouth area above the first node of the Don delta, the level surface was significantly influenced by the flow discharge, whereas in its lower section - by the water level in the Taganrog Bay.
\end{abstract}

Keywords: streamflow, river delta, Saint-Vevant equations, mathematical model, swing-surge oscillations, computational experiment.

Acknowledgments: the study is carried out within the framework of the state task of SSC RAS, state registration of the project is No. AAAA-A18-118122790121-5. The calculations are performed at the cluster of the Multiple-Access Center (MAC) "High-duty computations".

For citation: Chikin, A.L., Kleshchenkov, A.V. and Chikina, L.G., 2019. Numerical Study of the Water Flow Effect on the Water Level in the Don Mouth. Physical Oceanography, [e-journal] 26(4), pp. 316-325. doi:10.22449/1573-160X-2019-4-316-325

DOI: $10.22449 / 1573-160 \mathrm{X}-2019-4-316-325$

(C) 2019, A. L. Chikin, A. V. Kleshchenkov, L. G. Chikina

(C) 2019, Physical Oceanography

\section{Introduction}

Mouth areas of rivers, despite their relatively small size, occupy a special and very important place in the composition of both natural ecosystems and territorialeconomic complexes. They also play a crucial role in maintaining the global ecological balance [1]. Due to their advantageous geographical position (at the intersection of waterways from the continents to the seas and oceans and vice versa), the mouths of the rivers have become a place for construction of ports and formation of large industrial centers. The exceptional bio-productivity and widespread use of land, plant, fish and other resources of river mouths by various sectors of the economy have led to the fact that the areas of river deltas have 
become densely populated. At the same time, the use of river mouths is difficult due to the great variability of their morphological, hydrological, hydrochemical and ecological characteristics of short-term (tides, storms and surges) and seasonal scales.

The Don mouth is a key area of the Azov Sea basin, where complex processes of interaction of river and sea waters take place [2]. It extends $291 \mathrm{~km}$ from the conditional line connecting the Dolzhanskaya and Belosarayskaya spits in the Taganrog Bay, in the west to Razdorskaya village in the east [3, 4]. The Don mouth area consists of the estuarine section of the river (from Razdorskaya village to the top of the delta near Rostov-on-Don), its delta and the Taganrog Bay. It is characterized by the manifestation of pressure-level fluctuations here, the flow of transformed marine waters into the Don delta branches, which was especially pronounced during the period of low water 2007-2017 [5].

The Taganrog Bay of the Azov Sea and the Don mouth area is currently characterized by a complex combination of fresh, slightly brackish and brackish waters: 6 basic types of water masses are formed here. It was found that in the mouth area, even during surges, a significant salinity increase is recorded (up to 5\%), which indicates a sharply risen role of the Azov-Black Sea compensation current $[6,7]$. The research area is well developed in terms of maritime activities, shipping is also developed here. More than $40 \%$ of Russian grain exports annually pass through the ports of Azov (Rostov-on-Don, Azov and Taganrog). Due to the significant influence of overtaking phenomena in the Don mouth area, situations often arise when vessels are forced to stand idle for several days in the eastern part of the Taganrog Bay (the receiving buoy area of the AzovDon Shipping Canal) and on the roads of the ports of Azov and Rostov. Thus, on October 24, 2016, the movement of 45 vessels was stopped for almost a week due to a sharp decrease in water level [8].

The present paper is aimed to establish the regularities of the formation of the level regime in the channel and delta sections of the Don River valley at different volumes of river flow in the conditions of the level variability of the receiving reservoir - the Taganrog Bay. The solution to this problem seems important, since the hydrodynamic interaction of the riverbed and sea sections of the mouth area controls the transportation of both solid and dissolved substances [9], including toxic ones [10] and is of key importance for environmental management in the Don delta.

\section{Materials and Methods}

So far, many approaches have been developed for calculating the hydrological characteristics of streamflows. In [11], it is proposed to calculate free surface levels for the Don riverbed according to the following formula

$$
\frac{\Delta H_{x}}{\Delta H_{\mathrm{Az}}}=e^{-k x},
$$

where $\Delta H_{x}-$ surge in $x$ section; $\Delta H_{\mathrm{Az}}-$ surge in the Azov; $k=1,21 \cdot 10^{-5} Q_{\text {Razd }}+0,011, Q_{\text {Razd }}$ - water discharge at a post in Razdorskaya; $x-$ distance from Azov. However, the calculation by this method gives satisfactory 
results only in years when the water discharge is close to normal (slightly overestimated result with an error not exceeding 7\%). In addition, this technique does not work in the case when $\Delta H_{\mathrm{Az}}$ and $\Delta H_{x}$ have different signs.

The work [5] proposes an approach for estimating discharges and levels in the Don Delta on the basis of ideas about the water flow unsteadiness, but the issue of their changes due to fluctuations in discharge volumes was not considered. In [12], an example is given of a joint consideration of the variability of river discharge and surge fluctuations in the level of a closing reservoir.

The present work is a continuation of the studies presented in [13]. The delta areas is expanded to the boundary with the Taganrog Bay and includes three main branches of the Don: the Old Don, the Bolshaya Kalancha, passing into the Mokraya Kalancha and the Bol'shaya Kuterma. The movement of water in an open riverbed is described in many classical textbooks $[14,15]$ by the following system of differential equations:

$$
\left\{\begin{array}{l}
\frac{\partial Q}{\partial t}+g W\left(\frac{\partial z}{\partial s}+\frac{Q|Q|}{K^{2}}\right)=0 \\
\frac{\partial W}{\partial t}+\frac{\partial Q}{\partial s}=q
\end{array}\right.
$$

where $Q$-water discharge, $\mathrm{m}^{3} / \mathrm{s} ; t$ - time, $\mathrm{c} ; W$ - discharge section area, $\mathrm{m}^{2} ; z-$ water level, $\mathrm{m} ; s$ - the coordinate, $\mathrm{m} ; K$-discharge module, $\mathrm{m}^{3} / \mathrm{s} ; q$-distributed lateral inflow, $\mathrm{m}^{2} / \mathrm{s} ; g=9.81-$ the accepted value of free fall acceleration, $\mathrm{m} / \mathrm{s}^{2}$. The discharge module $K$ is calculated according to the formula $K=W \cdot C \sqrt{R}$, where $R$ - hydraulic radius; $C$ - Chezy's coefficient, obtained by the Manning formula $C=R^{1 / 6} / n, n$ - bottom roughness.

At the upper boundary of the flow, at the apex of the mouth area near Razdorskaya, the water discharge was set. At the lower boundary, the water level in the receiving reservoir - the Taganrog Bay, was set. This parameter was set equal to the amount of surge in the eastern part of the bay. At the branching points, the condition was set that the total water discharge rate over the branches was equal to zero. As the initial condition, the morphometric values of the depth and width of the riverbed were set in accordance with the Atlas of Inland Waterways of the Russian Federation [16] and the data of measurements carried out at the Southern Scientific Center (SSC) of RAS. It was believed that the water discharge rate in the calculation area is equal to the flow rate at the upper boundary and the change in the water surface is equal to zero or any known distribution: $Q(s, 0)=Q_{0}(s), \quad z(s, 0)=z_{0}(s)$.

Suppose that the cross section of the riverbed has a parabolic profile $z=\alpha x^{2}-H_{0},-b_{0} / 2 \leq x \leq b_{0} / 2$, where $z$-bottom profile; $\alpha=4 H_{0} / b_{0}^{2}-$ parabola coefficient; $H_{0}$ and $b_{0}$ - initial values of the maximum depth and width of the riverbed, respectively. Then the free surface of the water at an arbitrary point in time is at a level $z+H_{0}$. The riverbed width $b$ depends on the height of the level 
surface and is calculated by the formula $b=2 \sqrt{\frac{z+H_{0}}{\alpha}}$, and the flow section area is calculated accordingly as $W=\frac{2}{3} b\left(z+H_{0}\right)=\frac{4}{3 \sqrt{\alpha}}\left(z+H_{0}\right)^{\frac{3}{2}}$. Then we have $\frac{\partial W}{\partial t}=\frac{\partial W}{\partial z} \frac{\partial z}{\partial t}$, and given that $\frac{\partial W}{\partial z}=\frac{2}{\sqrt{\alpha}} \sqrt{z+H_{0}}=b$, we obtain $\frac{\partial W}{\partial t}=b \frac{\partial z}{\partial t}$. System (1) can be rewritten as

$$
\left\{\begin{array}{l}
\frac{\partial Q}{\partial t}+g W\left(\frac{\partial z}{\partial s}+\frac{Q|Q|}{K^{2}}\right)=0 \\
b \frac{\partial z}{\partial t}+\frac{\partial Q}{\partial s}=q
\end{array}\right.
$$

This problem is solved by finite-difference methods using implicit schemes. The following finite-difference approximation is applied to the system (2) on a four-point pattern:

$$
\left\{\begin{array}{l}
\frac{\left(Q_{j+1}^{n+1}-Q_{j+1}^{n}\right)+\left(Q_{j}^{n+1}-Q_{j}^{n}\right)}{2 \Delta t}+g W_{j}^{n}\left(\frac{z_{j+1}^{n+1}-z_{j}^{n+1}}{\Delta s}+\frac{Q_{j}^{n+1}\left|Q_{j}^{n}\right|}{K_{j}^{n 2}}\right)=0, \\
b_{j}^{n} \frac{\left(z_{j+1}^{n+1}-z_{j+1}^{n}\right)+\left(z_{j}^{n+1}-z_{j}^{n}\right)}{2 \Delta t}+\frac{Q_{j+1}^{n+1}-Q_{j}^{n+1}}{\Delta s}=q_{j}^{n} .
\end{array}\right.
$$

The scheme above was used in [17, 18] when calculating flows in natural channels; its stability is also proved there.

To solve the resulting system of linear algebraic equations, in this paper the direct method using the LU decomposition is used in the present study [19].

\section{Results and Discussion}

The model was debugged using data on water discharge and water surface levels at the hydrological stations (HS) in Razdorskaya, Bagaevskaya, Aksai, Rostov-on-Don and Donskoy from March 10 to May 7, 2018. It was assumed that the lateral tributaries $q$ were absent $(q=0)$ The water discharge and free surface level variation on the HS is shown in Tab. 1. To assess the results used $5 \%$ of the scope (variations) of the level for each HS.

By setting the level at Donskoy HS and the corresponding water discharge rate, the levels of the remaining four HSs were calculated. The account was held until a steady decision was obtained. The variation of the level values on the HS was determined by the selection of roughness coefficients in each of the sections of the riverbed, taking into account the work previously carried out at the SSC RAS [20]. The result was considered satisfactory if the calculated level differed from the observed value by no more than $5 \%$ of the corresponding magnitude. 
Values of variations of the free surface level and their $5 \%$-portions at the hydrological stations

\begin{tabular}{l|cc|c|c}
\hline \multirow{2}{*}{ Hydrological station } & \multicolumn{2}{|c|}{ Level, $\mathrm{m}$} & $\begin{array}{c}\text { Amplitude of } \\
\text { water level, } \\
\mathrm{m}\end{array}$ & $\begin{array}{c}\text { 5\% of level } \\
\text { amplitude, } \\
\mathrm{m}\end{array}$ \\
\cline { 2 - 3 } Razdorskaya & Minimum & Maximum & 4.41 & 0.22 \\
Bagaevskaya & 1.01 & 5.42 & 3.44 & 0.17 \\
Aksai & -0.01 & 3.43 & 2.27 & 0.11 \\
Rostov-on-Don & -0.69 & 1.58 & 2.15 & 0.11 \\
Donskoy & -0.85 & 1.30 & 2.40 & 0.12 \\
\hline Flow discharge $Q, \mathrm{~m}^{3} / \mathrm{s}$ & -1.22 & 1.18 & 1649 & 82 \\
\hline
\end{tabular}

The entire range of water discharge for the specified period was conditionally divided into 4 intervals: a reduced rate of $371-597 \mathrm{~m}^{3} / \mathrm{s}$ with an average value of $496 \mathrm{~m}^{3} / \mathrm{s}$; increased rate of $758-926 \mathrm{~m}^{3} / \mathrm{s}$ with an average value of $837 \mathrm{~m}^{3} / \mathrm{s}$; high rate $1062-1532 \mathrm{~m}^{3} / \mathrm{s}$ with an average value of $1404 \mathrm{~m}^{3} / \mathrm{s}$; very high rate of $1605-$ $2008 \mathrm{~m}^{3} / \mathrm{s}$ with an average value of $1879 \mathrm{~m}^{3} / \mathrm{s}$. It was found that for this model different roughness coefficients are required depending on the discharge rate. So, for a low norm and a very high discharge rate in all sections of the riverbed, the coefficient is approximately $0.010-0.015$. But for high and high discharges, the roughness coefficient in the areas upstream from the mouth to the Razdorskaya HS is different: on the section to the Rostov-on-Don HS, it is 0.322 (increased) and 0.360 (high); on the Rostov-on-Don - Aksai section, 0.135 (high) and 0.184 (high); on the Aksai - Bagaevskaya section, 0.029 (high) and 0.039 (high); in the Bagaevskaya - Razdorskaya section, approximately 0.016 at all the discharges. The variation in roughness coefficients is schematically shown in Fig. 1.

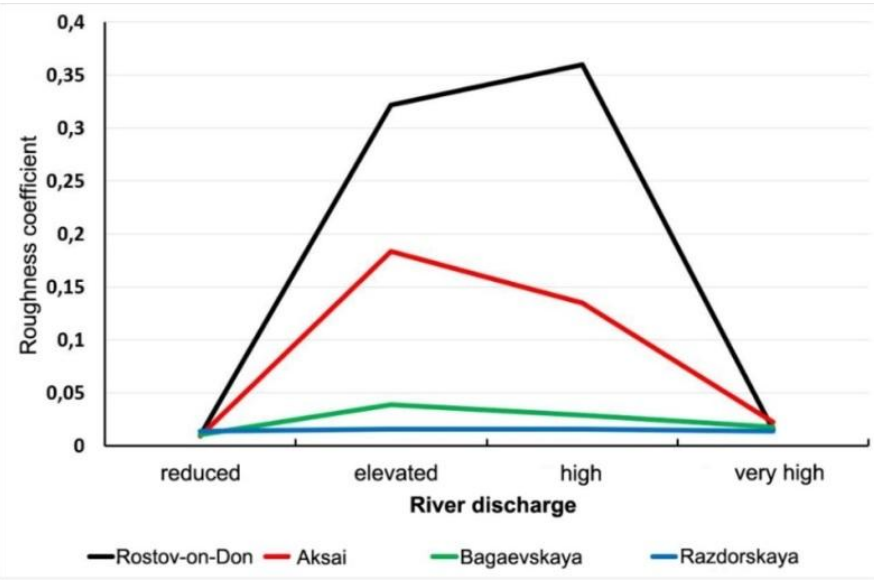

F i g. 1. Graphs of variation of the roughness coefficients 
Correlation analysis showed that the dependence between the water discharge rate and the water surface level weakens when moving downstream (Tab. 2). Moreover, after a branch from the main branches of the Don riverbed, the water surface level is practically independent of the water discharge $(r=0,29)$.

Ta ble 2

Correlation coefficients $(r)$ and significance levels $(p)$ for dependence of the free surface levels on water discharge $(Q)$

\begin{tabular}{lcc}
\hline \multicolumn{1}{c}{ Hydrological station } & $r$ & $p$ \\
\hline Razdorskaya & 0.99 & 0.00 \\
Bagaevskaya & 0.98 & 0.00 \\
Aksai & 0.93 & 0.00 \\
Rostov-on-Don & 0.86 & 0.00 \\
Donskoy & 0.29 & 0.01 \\
\hline
\end{tabular}

The calculated values of water discharge $(Q)$ and flow velocity $(V)$ were compared with the values ( $\left.Q_{\mathrm{obs}}, V_{\mathrm{obs}}\right)$ obtained on September 22-23, 2014. The measurements were carried out at the stations shown in Fig. 2. For the same points, calculations were performed using the considered model. The error was determined as follows: $\delta=\frac{\left|x-x_{\mathrm{n}}\right|}{\max \left(x, x_{\mathrm{n}}\right)}$ (where $x$ - estimated value, $x_{\mathrm{n}}-$ observed value) and couldn't exceed $100 \%$.

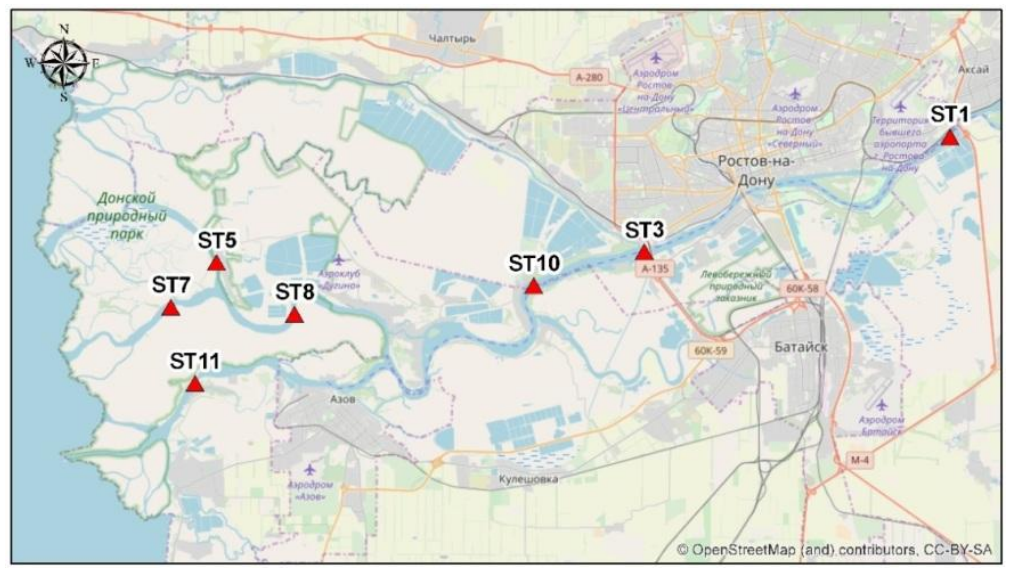

F i g. 2. Location of the stations in the Don delta branches in 2014

On September 22, the water level down to $-0.61 \mathrm{~m}$ at Donskoy HS was monitored, water discharge at the station 1 (Aksai HS) was $453 \mathrm{~m}^{3} / \mathrm{s}$, but on September 23, the level increased to $-0.36 \mathrm{~m}$, and the flow rate dropped to $303 \mathrm{~m}^{3} / \mathrm{s}$, which introduced significant errors in the measurements. The results obtained were compared with the observed data at the stations 3, 8, 10, 11 (Tab. 3). PHYSICAL OCEANOGRAPHY VOL. 26 ISS. 4 (2019) 
Table 3

Comparison the calculated values of flow velocity $(V)$ and water discharge $(Q)$ with the observed values $\left(Q_{\text {obs }}\right)$ and $\left(V_{\text {obs }}\right)$ at water levels -0.61 and $-0.36 \mathrm{~m}$

\begin{tabular}{|c|c|c|c|c|c|c|}
\hline Station & $\begin{array}{l}V_{\mathrm{obs}}, \\
\mathrm{m} / \mathrm{s}\end{array}$ & $V, \mathrm{~m} / \mathrm{s}$ & Error, \% & $\begin{array}{l}Q_{\text {obs }}, \\
\mathrm{m}^{3} / \mathrm{s}\end{array}$ & $Q, \mathrm{~m}^{3} / \mathrm{s}$ & Error, $\%$ \\
\hline \multicolumn{7}{|c|}{ water level $-0.61 \mathrm{~m}$} \\
\hline 3 & 0.281 & 0.260 & 7.47 & 457 & 456.1 & 0.20 \\
\hline 8 & 0.063 & 0.130 & 51.54 & 104 & 300.2 & 65.36 \\
\hline 10 & 0.196 & 0.250 & 21.60 & 382 & 501.2 & 23.78 \\
\hline 11 & 0.139 & 0.150 & 7.33 & 152.5 & 201.2 & 24.20 \\
\hline \multicolumn{7}{|c|}{ water level $-0.36 \mathrm{~m}$} \\
\hline 3 & 0.281 & 0.250 & 11.03 & 457 & 455.9 & 0.24 \\
\hline 8 & 0.063 & 0.120 & 47.50 & 104 & 273.1 & 61.92 \\
\hline 10 & 0.196 & 0.220 & 10.91 & 382 & 455.9 & 16.21 \\
\hline 11 & 0.139 & 0.130 & 6.47 & 152.5 & 183.0 & 16.67 \\
\hline
\end{tabular}

Station 8 was located in the Kalancha branch, where, most likely, during the considered observation period, due to weather conditions, a direct relationship between the water discharge and the level was disrupted. The error for this station is significantly higher than the others. The large error in the flow velocity is probably explained by the error in the task of the transverse profile of the riverbed, which directly affects the flow section and, therefore, the flow velocity.

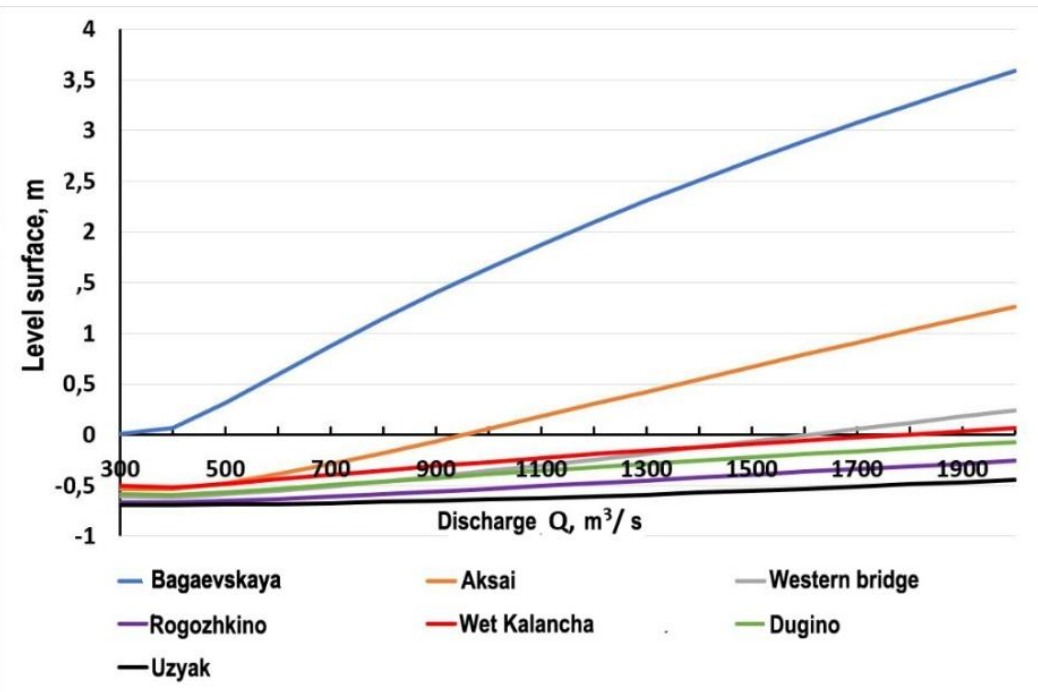

F i g. 3. Change of the water level at the stations relative to the standard depending on the flow discharge $Q$ at water level $-0.7 \mathrm{~m}$ (Baltic system) 
A numerical study of the influence of the water flow amount at the apex of the mouth area on the water surface level in the riverbed at different levels in the receiving reservoir - the Taganrog Bay. Water discharge varied from $300 \mathrm{~m}^{3} / \mathrm{s}$ (in the low-water period) to $2000 \mathrm{~m}^{3} / \mathrm{s}$ (in the high-water period). A computational experiment showed that the water surface level substantially depends on the water discharge rate only on the main riverbed HSs (Bagaevskaya and Aksai). Moreover, this occurs both during surge and at a neutral level. In the delta area, the effect of water discharge on the level surface of the riverbed begins to weaken significantly. So that, during the water level $(-0.7 \mathrm{~m})$, the difference in levels at the highest and lowest discharge rates in the first node of the delta at the station 3 (Zapadniy Most) did not exceed $0.85 \mathrm{~m}$. At the stations in the Don Delta itself (Dugino (Station 8), Mokraya Kalancha (Station 7), Rogozhkino (Station 5), Uzyak (Station 11)) this difference did not exceed $0.6 \mathrm{~m}$ (Fig. 3).

During the surge, an increased discharge of water into the mouth area allows maintaining the normal passage depth of the ship's course, but, as calculations have shown, this is ineffective in the Don delta.

Computational experiment carried out using a mathematical model showed the following results. In the absence of surges, the level surface fluctuation at the lowest and highest water discharge rates does not exceed $0.55 \mathrm{~m}$ at the first node of the delta and $0.3 \mathrm{~m}$ at stations in the Don delta itself.

At the same time, the Don delta level is significantly affected by surge phenomena and not by the water discharge amount. So, with a surge of $1.5 \mathrm{~m}$ at the mouths of the Don branches, the water level at the stations in the delta also rose by about $1.5 \mathrm{~m}$ and practically did not depend on the amount of water entering the mouth. The dependence of the riverbed surface level on the water discharge when moving upstream also decreases. Observations of the water level at Donskoy HS confirm the results obtained by calculation.

A comparison of the current velocities at the stations in the absence of surges at different discharges of runoff water (Tab. 4) showed that the velocity variations in the delta area of the riverbed (Mokraya Kalancha, Dugino and Uzyak) are much smaller than in the main riverbed (Aksay, Zapadniy Most). This is explained by a significantly smaller effect of the incoming water discharge on the hydrodynamics of the Don delta branches.

Table 4

Variations of the flow velocity values $V$ at the stations

\begin{tabular}{lc}
\hline \multicolumn{1}{c|}{ Stations } & Amplitude of $V, \mathrm{~m} / \mathrm{s}$ \\
\hline Aksai & 0.93 \\
Zapadny most & 0.76 \\
Mokraya Kalancha & 0.46 \\
Dugino & 0.41 \\
Uzyak & 0.47 \\
\hline
\end{tabular}

PHYSICAL OCEANOGRAPHY VOL. 26 ISS. 4 (2019) 


\section{Conclusion}

Calculations carried out using the mathematical model, as well as observations of water discharge and variations in the water surface level showed that the hydrological situation in the Don Delta is significantly affected by the level in the receiving reservoir - the Taganrog Bay. The discharge rate of water entering the mouth area affects the level regime of the Don riverbed, located above the place of division into the branches. Moreover, with the advancement upstream, this influence increases. In the delta part of the Don, the water discharge rate at Razdorskaya HS practically does not affect the level regime.

\section{REFERENCES}

1. Mihajlov, V.N., 1997. [Rivers Mouths of Russia and Neighboring Countries: Past, Present and Future]. Moscow: GEOS, 413 p. (in Russian).

2. Filippov, Y.G., 2015. The Impact of the Don River Runoff on the Water Level in the Taganrog Bay. Russian Meteorology and Hydrology, [e-journal] 40(2), pp. 127-130. https://doi.org/10.3103/S1068373915020090.

3. Ostroumova, L.P., 2017. Investigation of Surges in Marine Estuaries (A Case Study for the Don River Mouth). Russian Meteorology and Hydrology, [e-journal] 42(12), pp. 792-802. https://doi.org/10.3103/S106837391712007X

4. Simov, V.G., 1989. [Hydrology of the Mouths of the Rivers of the Sea of Azov]. Moscow: Gidrometeoizdat: 328 p. (in Russian).

5. Mishin, D.V. and Polonskiy, V.F., 2013. Research of Non-Stationary Water Streams in Nontidal Mouth of Don River. In: SOI, 2013. Trudy GOIN [SOI Proceedings]. Moscow: SOI. Iss. 214, pp. 166-179 (in Russian).

6. Matishov, G.G. and Grigorenko, K.S., 2017. Causes of Salinization of the Gulf of Taganrog. Doklady Earth Sciences, [e-journal] 477(1), pp. 1311-1315. https://doi.org/10.1134/S1028334X17110034

7. Matishov, G.G., Kovaleva, G.V. and Yasakova, O.N., 2016. Anomalous High Salinity in the Taganrog Bay Estuary and the Don Delta. Nauka Yuga Rossii = Science of the South of Russia, 12(1), pp. 43-50 (in Russian).

8. Matishov, G.G. and Ermolaev, A.I., 2017. The World of Glossy Ibis and Coastal Areas as Perceived by the Don Cossacks. Rostov-on-Don: Publ. SSC RAS, 224 p. (in Russian).

9. Hiatt, M., Snedden, G., Day, J.W., Rohli, R.V., Nyman, J.A., Lane, R. and Sharp, L.A., 2019. Drivers and Impacts of Water Level fluctuations in the Mississippi River Delta: Implications for Delta Restoration. Estuarine, Coastal and Shelf Science, [e-journal] 224, pp. 117-137. https://doi.org/10.1016/j.ecss.2019.04.020

10. de Souza Machado, A.A., Spencer, K., Kloas, W., Toffolon, M. and Zarfl, C., 2016. Metal Fate and Effects in Estuaries: A Review and Conceptual Model for Better Understanding of Toxicity. Science of the Total Environment, [e-journal] 541, pp. 268-281. doi:10.1016/j.scitotenv.2015.09.045

11. Mikhailov, V.N., Rogov, M.M. and Chistyakov, A.A., 1986. [River Deltas (HydrologicalMorphological Processes)]. Leningrad: Hydrometeoizdat, 280 p. (in Russian).

12. Polonskii, V.F. and Ostroumova, L.P., 2002. Probabilistic Estimates of Water Level in the Ural River Mouth Reach at Interaction between the River Runoff and Positive Setups. Water Resources, [e-journal] 29(5), pp. 497-505. https://doi.org/10.1023/A:1020365512557

13. Chikin, A.L., Kleshchenkov, A.V., Chikina, L.G., Korshun, A.M., 2017. Wind-Driven Water Level Variation of the Mouth Area of the Don: Numerical Modelling and Change Scenarios. Nauka Yuga Rossii = Science of the South of Russia, 13(3), pp. 39-49 (in Russian).

14. Grushevskij, M.S., 1969. [Waves of Releases and Floods in Rivers]. Leningrad: Gidrometeoizdat, 337 p. (in Russian). 
15. Koren', V.I., 1991. [Mathematical Models in River Flow Forecasts]. Leningrad: Gidrometeoizdat, 197 p. (in Russian).

16. GBU "Volgo-Balt", 2006. [Atlas of the Unified Deep-Water System of the European Part of Russia. Volume 8. Part 2. Volga-Don Waterway. From Volgodonsk to the Mouth of the Don]. Saint-Petersburg: Volgo-Balt, 40 p. (in Russian).

17. Amein, M. and Fang, C.S., 1970. Implicit Flood Routing in Natural Channels. Journal of the Hydraulics Division, 96(12), pp. 2481-2500.

18. Fread, D.L., 1974. Numerical Properties of Implicit Four-Point Finite Difference Equations of Unsteady Flow. NOAA Technical Memorandum NWS Hydro-18. Silver Spring, MD: U.S. Department of Commerce, NOAA, 123 p. Available at:

https://www.nws.noaa.gov/oh/hdsc/Technical_memoranda/TM18.pdf [Accessed: 10.07.2019].

19. Forsythe, G.E. and Moler, C.B., 1967. Computer Solution of Linear Algebraic Systems. Englewood Clis, NJ: Prentice-Hall, 167 p.

20. Sheverdyaev, I.V., 2018. [Investigation of the Streambed Roughness at the Delta of the River Don, by Water Level Observations in May 2018]. In: SSC RAS, 2018. Ekologija. Ekonomika. Informatika. Serija: Sistemnyj Analiz i Modelirovanie Jekonomicheskih i Ekologicheskih Sistem [Ecology. Economy. Informatics. System Analysis and Mathematical Modeling of Ecological and Economic Systems]. Rostov-on-Don: Publ. SSC RAS. Vol. 1, iss. 3, pp. 276279. doi:10.23885/2500-123x-2018-2-3-49-57 (in Russian).

\section{About the authors:}

Aleksey L. Chikin - Chief Research Associate, Federal Research Centre the Southern Scientific Centre of Russian Academy of Sciences (41 Chekov St., Rostov-on-Don, 344006, Russian Federation), Dr.Sci. (Physics\&Math), SPIN-код: 3845-9760, ORCID ID: 0000-0002-4065-010X, Scopus Author ID: 8240627300, chikin1956@gmail.com

Aleksey V. Kleshchenkov - Leading Research Associate, Federal Research Centre the Southern Scientific Centre of Russian Academy of Sciences (41 Chekov St., Rostov-on-Don, Russia, 344006), PhD (Geogr.), ResearcherID: E-6619-2014, ORCID ID: 0000-0002-7976-6951, Scopus Author ID: 57016697100, geo@ssc-ras.ru

Lyubov G. Chikina - Professor, Southern Federal University (105 Bolshaya Sadovaya St., Rostov-on-Don, 344006, Russian Federation), Dr.Sci. (Physics\&Math), SPIN-код: 4295-3950, ORCID ID: 0000-0002-2935-5839, Scopus Author ID: 6506085787, lchikina@ @fedu.ru

Contribution of the co-authors:

Aleksey L. Chikin - the research initiator; development of a mathematical model; preparation of the initial version of the text; revision of the text; constructing tables, graphs and charts

Aleksey V. Kleshchenkov - formulation of the goals and objectives of the study; writing annotations; analysis and synthesis of research results; formulation of conclusions; literature review on the research; data collection and systematization; constructing tables, graphs and charts; computer work

Lyubov G. Chikina - selection and justification of numerical methods for solving equations; correction of the mathematical model and calculations; computer implementation of the algorithms

All the authors have read and approved the final manuscript.

The authors declare that they have no conflict of interest. 